NBER WORKING PAPER SERIES

EXPECTED INFLATION AND EQUITY PRICES:

A STRUCTURAL ECONOMETRIC APPROACH

David S. Jones

Working Paper No. 542

NATIONAL BUREAU OF ECONOMIC RESEARCH

1050 Massachusetts Avenue

Cambridge MA 02138

September 1980

Financial assistance for this study from the Sloan Foundation and Data Resources, Inc. is gratefully acknowledged. The research reported here is part of the NBER's research program in Financial Markets and Monetary Economics. Any opinions, findings, or conclusions expressed herein are those of the author and do not necessarily reflect the views of the Sloan Foundation, Data Resources, Incorporated, or the National Bureau of Economic Research. 


\section{Expected Inflation and Equity Prices: A \\ Structural Econometric Approach}

\section{ABSTRACT}

The purpose of the present paper is to investigate the effects of expected inflation on the general level of common stock prices using a structural rather than a reduced-form approach. To this end, an aggregative partial-equilibrium structural econometric model of the U.S. equity market is constructed using quarterly flow-of-funds data. The primary endogenous variable in this model is the Standard and Poor's Index of 500 Common Stock Prices, P. After passsing several standard validation exercises the model is used to perform a number of simulation experiments designed to assess the impact of expected inflation on $P$. To anticipate, we find that increases in expected inflation depress current equity prices by about the same amount as found in a related study of Modigliani and Cohn: a 100 basis point increase in expected inflation, holding real interest rates constant, is predicted to lower the general level of equity prices by $7.8 \%$.

In the course of constructing the structural equity market model equity demand equations are estimated for households, life insurance companies, open-end investment companies, property and casualty insurance companies, and state and local government retirement systems. Equations are also estimated for the demand for mutual fund shares by households and equity issues by U.S. nonfinancial corporations.

David S. Jones Department of Economics Northwestern University Evanston, Illinois 60201 (312) 492-5690 


\section{Introduction}

Prior to the protracted escalation in the rate of inflation beginning in the late sixties conventional economic wisdom maintained that common stock prices were a hedge against inflation. This traditional view was fostered by the Fisher-Williams investment model which implies that the present value of an unlevered earnings stream is invariant to both anticipated and unanticipated inflation. ${ }^{l}$ For levered firms, this model implies that real equity prices should rise after periods of unanticipated inflation. Two early empirical studies carried out by Kessel (1956) and Bach and Ando (1957) appeared to support the hypothesis that real equity prices are unaffected by inflation.

Recent empirical studies by Bodie (1976), Jaffe and Mandelker (1976), Lintner (1973, 1975), Modigliani and Cohn (1979), and Nelson (1976), however, cast serious doubt upon the traditional view that real equity prices are invariant to inflation. Their common finding is that equities have historically failed to waintain their real values during periods of inflation. The Bodie, Jaffe and Mandelker, Modigliani and Cohn, and Nelson studies, moreover, suggest that equity prices respond negatively to increases in the expected rate of inflation alone. If correct, these results have important implications for optimal portfolio strategy, issues in capital formation as well as for countercyclical stabilization policy.

All of the above empirical studies share one common feature. Explicitly or implicitly all employ the single-equation reduced-form methodology to measure the effects of expected inflation on equity prices. Generally, a stock price or rate of return is regressed upon a set of 
explanatory variables which includes a proxy for expected inflation. The empirical finding of a negative regression coefficient associated with the expected inflation variable is then interpreted as evidence that an increase in expected inflation depresses stock prices. The purpose of the present paper is to investigate the effects of expected inflation on the general level of common stock prices using a structural rather than a reduced-form approach. To this end, an aggregative partial-equilibrium structural econometric model of the U.S. equity market is constructed using quarterly flow-of-funds data. The primary endogenous variable in this model is the Standard and Poor's Index of 500 Common Stock Prices, P. After passing several standard validation exercises the model is used to perform a number of simulation experiments designed to assess the impact of expected inflation on $P$. In the course of constructing the structural equity market model equity demand equations are estimated for households, life insurance companies, open-end investment companies, property and casualty insurance companies, and state and local government retirement systems. Equations are also estimated for the demand for mutual fund shares by households and equity issues by U.S. nonfinancial corporations.

Briefly, the plan of the paper is as follows: Section II summarizes the empirical findings of Modigliani and Cohn, to which we shall have occasion to compare our own results. The Modigliani-Cohn study chosen as a focus of comparison because it is well known, its empirical findings are broadly representative of those obtained in studies using the reduced-form approach, and because its time frame and data correspond most closely with our own. 
Section III sets forth the general theoretical specification of the equity demand and supply equations comprising the structural equity market model. Several econometric issues relating to estimating these equations are also discussed.

In Section IV, regression estimates of the above behavioral equations are presented.

Section $V$ combines these estimated structural equations with a number of accounting identities, bridge equations and a market clearing identity to form the structural equity market model. The results of several within-sample and out-of-sample historical tracing experiments are also reported.

The results of a number of simulation experiments using the structural equity market model to assess the effects of expected inflation on the general level of equity prices are reported in Section VI. To anticipate, we find that increases in expected inflation depress current equity prices by about the same amount as found by Modigliani and Cohn. A 100 basis point increase in expected inflation, holding real interest rates constant, is predicted to lower the general level of equity prices by $7.8 \%$.

Concluding comments are presented in Section VII. 
II. The Modigliani-Cohn Study

One of the most thorough studies of the effect of expected inflation on the general level of stock prices is that by Modigliani and Cohn. Their primary empirical finding is summarized in the regression equation reproduced in Figure 1. This regression is a reduced-form relationship explaining the logarithm of the Standard and Poor's stock price index, P, by current and past interest rates, a proxy for "equilibrium" adjusted earnings per share, and a proxy for expected inflation.

The Modigliani-Cohn equation implies that a 100 basis point increase in the expected rate of inflation, holding nominal interest rates constant, will result in approximately a $2.1 \%$ fall in P. A 100 basis point increase in expected inflation, holding real interest rates constant, is predicted to lower $\mathbf{P}$ by about $8 \%$.

In Section VI below, we present alternative estimates of the impact of expected inflation on P. Rather than estimating a reduced-form relationship for $P$ and then inferring the magnitude of this effect from the estimated coefficients, as is done by Modigliani and Cohn, we shall construct a structural econometric model for $\mathrm{P}$ and then simulate this model to obtain estimates of the effect of expected inflation on $P$. 


\section{Figure 1}

THE MODIGLIANI-COHN REDUCED-FORM EQUITY PRICE EQUATION

$$
\begin{aligned}
& \log [P]=(26.4)+\sum_{i} \alpha_{i} \pi_{-i}+\sum_{j} \beta_{j} \operatorname{div}_{-j}+\sum_{k} \gamma_{k} \cdot\left(L F{ }_{-k} / E M P-k\right) \\
& -\underset{(3.7)}{.048 D V F}-\sum_{\mathbf{n}_{i}} \gamma_{m} R_{A A,-m}+\sum_{n} w_{n} \cdot\left(C P I_{-n} / C P I_{-n-1} 1\right) \cdot 400 \\
& +.74 \tilde{U}_{-1} \\
& \sum \alpha_{i}=1 \text { (constrained) SER (with error feedback) }=.042 \\
& \text { i SER (without error feedback) }=.063 \\
& \begin{array}{ll}
\sum_{j} \beta_{j}=0 \text { (constrained) } \quad \text { D.W. }=1.54
\end{array} \\
& \begin{array}{l}
\sum \gamma_{k}=\underset{k}{6.5} \\
(4.2)
\end{array} \quad \text { SAMPLE PERIOD: 1953:1 - 1977:4 }
\end{aligned}
$$

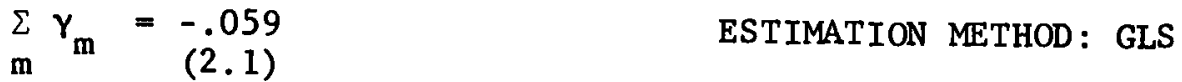

$$
\begin{aligned}
& \sum_{\mathbf{n}} \omega_{\mathrm{n}}=-.021
\end{aligned}
$$

where

$$
\begin{aligned}
& \text { P = the Standard and Poor's } 500 \text { stock price index, } \\
& \pi_{-i}=\text { the logarithm of earnings per share of the } S \& P \text { lagged "i" }
\end{aligned}
$$


III. Specification of the Behavioral Equations of the Structural Equity Market Model

Conceptually, the investors (borrowers) in our model are assumed to have vectors of net asset demands (issues) which are well described by a version of Brainard and Tobin's (1968) multi-asset stock adjustment model. Specializing this system to the relationship for equities we obtain:

(1) $\Delta E Q_{t}=\left(\alpha+\underline{\beta}^{T} \underline{r}_{t}^{e}+\underline{\gamma}^{T} \underline{x}_{t}\right)\left(W_{t-1}+\Delta W_{t}\right)-\underline{\lambda}^{T} \underline{A}_{t-1}+\tilde{\epsilon}_{t}$ where $\Delta E Q_{t}=$ net acquisitions (gross issues) of equities in period " $t$ ",

$\alpha=$ a coefficient to be estimated,

$\underline{B}=$ a coefficient vector to be estimated,

$\underline{r}_{t}^{e}=a$ vector of expected net after tax real rates of return on the assets (liabilities) available to the investor (borrower) group,

$\chi=$ a coefficient vector to be estimated,

$\underline{x}_{t}=$ a vector of additional explanatory variables reflecting institutional considerations and seasonal factors,

$\mathrm{W}_{t-1}=$ the market (replacement) value of the investor (borrower) group's financial (real and financial) assets at the end of period " $t-1$ ",

$\Delta W_{t}=$ net acquisition of financial (net funds raised in financial markets) during period " $t$ ",

$\underline{\lambda}=$ a coefficient vector to be estimated,

$\underline{A}_{t-1}=$ the complete vector of asset holdings (1iabilities) at the end of period " $t-1$ ", and

$\tilde{\epsilon}_{t}=$ a zero-mean residual error displaying heteroscedasticity of 
the form:

$$
\sigma_{t}^{2}=\gamma_{1}\left(W_{t-1}+\Delta W_{t}\right)^{2}+\gamma_{2}
$$

where $\gamma_{1}$ and $\gamma_{2}$ are positive constants. ${ }^{2}$

The vector of expected after tax real rates of return, $\underline{r}_{t}^{e}$, in (1) is not directly observable. To circumvent this difficulty it is necessary to postulate a mechanism by which agents form expectations and then to insert this relation in place of $\underline{r}_{t}^{e}$ in (1). Since after tax rate of return data is not readily obtainable for most taxable investors it will prove convenient to rewrite (1) in terms of before tax, rather than after tax, yields before we specify the expectations formation mechanisms below.

By an argument similar to that in Jones (1979) it can be shown that if the effective income and capital gains tax rates on each asset are stable then equation (1) may be rewritten:

$$
\begin{aligned}
\Delta E Q_{t}= & \left(\alpha+\underline{\beta}_{I}^{T} \underline{R}_{I, t}^{e}+\underline{B}_{C G}^{T}-_{C G, t}^{e}+\beta_{\pi} \pi_{t}^{e}+\gamma^{T} \underline{x}_{t}\right) \cdot\left(W_{t-1}+\Delta W_{t}\right) \\
& -\underline{\lambda}^{T} \underline{A}_{t-1}+\tilde{\epsilon}_{t}
\end{aligned}
$$

where $\underline{\beta}_{I} \quad=$ a coefficient vector to be estimated,

$$
\begin{aligned}
& \underline{R}_{I, t}^{e}=\text { a vector of expected before tax nominal income yields, } \\
& \underline{B}_{C G}=\text { a coefficient vector to be estimated, } \\
& \underline{R}_{C G, t}^{e}=\text { a vector of expected before tax nominal capital gains yields, } \\
& \beta_{\pi}=\text { a coefficient to be estimated; and } \\
& \pi_{t}^{e}=\text { the expected rate of inflation. }
\end{aligned}
$$

Equation (2), is the generic specification of the structural equations estimated below. It relates net equity demands to before tax, rather than after tax, expected rates of return. The differential tax treatment of ordinary income and capital gains necessitates decomposing 
the total before tax yield vector into separate income and capital gains components. For tax exempt investors it may be shown that $\beta_{I}=\beta_{C G}$. In general, however, the coefficient vectors $\beta_{I}$ and $\beta_{C G}$ will not be proportional for taxable investors.

The data. The primary data source for the financial stock and flow variables used in this study is the Federal Reserve flow-of-funds accounts. A complete listing of all of the data used in this study and their sources or derivations is provided in Appendix 1 (available from the author on request).

Consistent with the approach taken by Friedman (1977, 1979) and Roley (1977), the wealth level and new wealth flow variables appearing in (2), (i.e., $W_{t-1}$ and $\Delta W_{t}$ ) are defined in terms of the discretionary portions of investors' portfolios. With the exception of households, life insurance companies, and property and casualty insurance companies, these wealth levels and new wealth flows are taken to be total financial assets and the quarterly net acquisition of financial assets respectively.

For households, $w_{t-1}$ is taken to be total financial assets less the net acquisition of life insurance and pension reserves. ${ }^{3}$ The variable $\Delta \mathrm{W}_{t-1}$ is correspondingly defined to be the quarterly net acquisition of financial assets less the sum of life insurance reserves and pension reserves.

The wealth level variable for life insurance companies is taken to be total financial assets less policy loans. ${ }^{4}$ The new wealth flow variable is defined to be the quarterly net acqusition of financial assets less the net increase in policy loans.

For property and casualty insurance companies, the wealth level variable is taken to be total financial assets less trade credit. ${ }^{5}$ New wealth flows are accordingly defined to be the quarterly net acquisition 
of financial assets less the net increase in trade credit.

The wealth variable $W_{t}$ in the nonfinancial corporate sector's equity issue equation is defined to be the replacement value of this sector's assets. ${ }^{6}$ The wealth flow variable $\Delta \mathrm{W}_{t}$ is taken to be quarterly net funds raised in financial markets plus gross equity retirements.

Before passing, it is worthwhile to mention several major shortcomings of the flow-of-funds data which we are using. First, the "quality" of this data varies markedly from sector to sector. While the data for S.E.C. regulated institutional investors is likely to be reasonably accurate, that for households, state and local government retirement systems and nonfinancial corporations is probably substantially less accurate.

Second, it is important to note that the "equity" concept employed in the flow-of-funds accounts includes preferred stocks. Since the structural equity market model below is primarily designed to explain common stock prices, a common stock equity concept is preferable. However, the construction of common stock flow-of-funds series would have been a major research undertaking in its own right and was not attempted. Some indication of the degree to which the flow-of-funds data are contaminated by preferred stocks may be gleaned from the fact that market value of the nonfinancial corporate sectors' preferred stocks was below $6 \%$ of the market value of their common stocks for all years between 1960 and 1976.

The modeling of expectations. In the regressions reported below, actual before tax income yields are approximated by yields to maturity, $\mathrm{R}_{\mathrm{t}}$, for debt securities and by the standard and Poor's dividend/price ratio, $\left(D_{t} / P_{t}\right)$, for equities. 
For long term debt securities, the actual one period before tax capital gains rate of return is approximated by the expression $-\left(R_{t}-R_{t-1}\right) / R_{t}$. while that for equities is taken to be the percentage rate of change of the Standard and Poor's stock price index (i.e., $\left.\left(P_{t}-P_{t-1}\right) / P_{t}\right)$.

Expected income yields are assumed to be equal to actual income yields in the regressions reported below. That is, the income yields on all assets are assumed to be perfectly predicted by investors. Thus, $\underline{R}_{I, t}^{e}=\underline{R}_{I, t}$. The expected before tax capital gains yields on long term bonds are modeled as univariate autoregressions of past actual one period capital gains yields. As is well known, Cagan's (1956) adaptive expectations model, Duesenberry's (1958) extrapolative expectations model, Keynes' (1936) regressive expectations model, Meiselman's (1962) error learning model, Modigliani and Shiller's (1972) regressive/extrapolative expectations model and Nelson's (1972) weak form rational expectations model are all special cases of the univariate autoregressive expectations model. The expected rate of inflation, $\pi_{t}^{e}$, is proxied below by a three year moving average of past actual rates of change of the consumer price index. Extensive collinearity between past rates of inflation and current and past nominal interest rates precluded the use of the more general univariate autoregressive expectations scheme for this variable.

Three alternative before tax equity capital gains expectation formation schemes were tried for each investor group. ${ }^{7}$ These schemes were: (i) An autoregressive expectations model in which the expected capital gains yield on equities is a univariate autoregression of past actual capital gains yields. 
(ii) A regressive expectations model wherein investors are assumed to have some idea of a "normal" dividend/price ratio, $(D / P)^{*}$, and the actual dividend/price ratio is expected to adjust toward this normal value over time according to:

$$
\left(D_{t+1} / P_{t+1}\right)-\left(D_{t} / P_{t}\right)=\theta\left[(D / P)^{*}-\left(D_{t} / P_{t}\right)\right]
$$

where $0<\theta<1$.

The expected equity capital gains yield is then approximately given by the expression:

$$
\left.\left(P_{t+1}^{e} / P_{t}\right)-I=\left(D_{t+1}^{e} / D_{t}-1\right)+\left[\theta /(D / P)^{*}\right] \cdot\left[D_{t} / P_{t}\right)-(D / P)^{*}\right]
$$

In the empirical implementation of this model below $(D / P) *$ and $\theta$ are taken to be constants while the expected growth rate of dividends per share, $\left(D_{t+1}^{e} / D_{t}-1\right)$, is modeled as a univariate autoregression. 8

(iii) The final expectations model is similar to (ii) except that investors are assumed to have some notion of a "normal" earnings/price ratio, $(E / P)^{*}$, for stocks.

Selection between these three alternative expectation formation models was based on the minimum mean-squared-error criterion.

The autoregressive expectations scheme (i) resulted in the lowest regression standard error for the major institutional investors: life insurance companies, private pension funds, open-end investment companies, and state and local government retirement systems. Scheme (ii) was selected for households while (iii) was chosen for property and casualty insurance companies. Only the final regression for each investor group is reported below. 
Estimation techniques. Estimation of equation (2) by ordinary least squares is not a valid statistical procedure since the equity income and capital gains yield variables are functions of the endogenous stock price term P. $^{9}$ A solution to this simultaneity problem would ordinarily be to estimate (2) by two-stage least squares (TSLS). However, this procedure is not feasible in our case because the number of exogenous variables in our complete model exceeds the number of observations in our sample period. An alternative limited information instrumental variable estimation technique described by Brundy and Jorgenson (1971) is employed below. This procedure differs from TSLS in that the set of instruments applied to each structural equation consists only of the exogenous variables in that equation plus at least as many principle components of the TSLS instrument set as are needed for identification. The first fifteen principle components of this set are used in each of the regessions reported below.

Equation (2) allows for the possibility that the regression residuals are heteroscedastic. For each of the regressions below a Glejser (1969) test for heteroscedasticity, as modified by Amemiya (1977), was performed. If the null hypothesis of no heteroscedasticity could not be rejected then no heteroscedasticity correction was applied to that regression.

This null hypothesis, however, was rejected in four out of the eight regressions. In these cases, however, the null hypothesis that $\gamma_{2}=0$ could not be rejected. Consequently, in these regressions each observation is deflated by the investible wealth variable $\left(\mathrm{W}_{t-1}+\Delta \mathrm{W}_{t}\right)$ to remove the suspected heteroscedasticity. 
IV. Estimation Results

Figure 2 reports the regression estimates for the equity demand equations of the structural equity market model. Included are estimated equations for the net acquisition of mutual fund shares by households and net acquisitions of equities by households, life insurance companies, open-end investment companies, private pension funds, property and casualty insurance companies and state and local government retirement systems. A brief listing of the variables appearing in these regressions can be found in Figure 4. It is important to bear in mind that all dollar amounts are in billions, all flows are at quarterly rates and all yields are expressed as percentages at annual rates. All regressions use seasonally unadjusted data and, with the exception of state and local government retirement systems, all sample periods run from 1960:1 through 1976:4. ${ }^{10}$

In estimating each demand equation an effort was made to include as explanators a short-term interest rate, a long-term bond yield, an expected long term bond capital gains yield proxy, and an expected inflation variable in addition to lagged asset holdings and the expected income and capital gains yields on equities. Supplemental explanators are sometimes also included on the basis of institutional considerations. Collinearity among the regressors was a major problem and as a general rule a variable was excluded from the specification if its estimated coefficient was not significantly different from zero.

Household demand for mutual fund shares. Regression (1) implies that households' demand for mutual fund shares varies positively with the dividend/ price ratio and expected growth rate of dividends. This demand varies negatively with respect to the commercial paper rate and the expected rate of inflation.

The positive coefficient associated with the long-term BAA corporate bond rate may reflect the fact that a substantial portion of the assets 
Figure 2

\section{REGRESSION ESTIMATES FOR EQUITY DEMAND EQUATIONS $^{a}$}

1. Household Demand for Mutual Fund Shares:

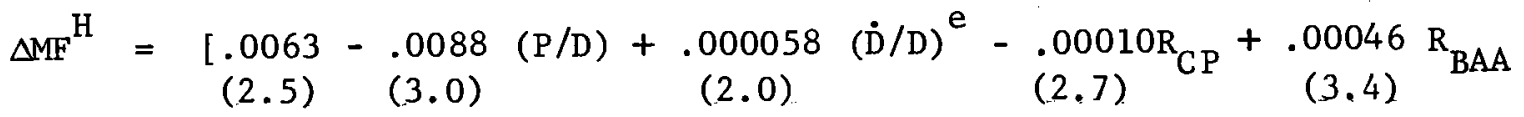

$$
\begin{aligned}
& -\underset{(3.6)}{.00031} \text { INFLATION }-\underset{(3.5)}{.00054} \text { TAXDUMMY }-\underset{(6.4)}{.00041} \text { SEAS } 2-\underset{(4.5)}{.00030 \text { SEAS3] }} \\
& \text { - }\left(\mathrm{W}_{-1}^{\mathrm{H}}+\Delta \mathrm{w}^{\mathrm{H}}\right)-\underset{(2.9)}{.097 \mathrm{MF}_{-1}^{\mathrm{H}}}+\underset{(2.2)}{.0046 \mathrm{EQ}_{-1}^{\mathrm{H}}}-\underset{(3.7)}{.13 \mathrm{STLOCAL}_{-1}^{\mathrm{H}}}
\end{aligned}
$$

where $(\dot{D} / D))^{e} \equiv 100 \sum_{i=1}^{11} \delta_{i} \cdot\left(D_{-i} / D_{-(i+1)}-1\right), \sum_{i} \delta_{i}=1^{b}$

SAMPLE PERIOD: ${ }^{c} \quad 1960: 1-1976: 4$

$$
\mathrm{R}^{2}=.82 \mathrm{R}^{-2}=.78 \text { SER }=.302 \text { billion }\left(\mathrm{D}-\mathrm{W}=2.02, \mathrm{t}_{\rho}=.30\right)
$$

\section{Household Demand for Equities:}

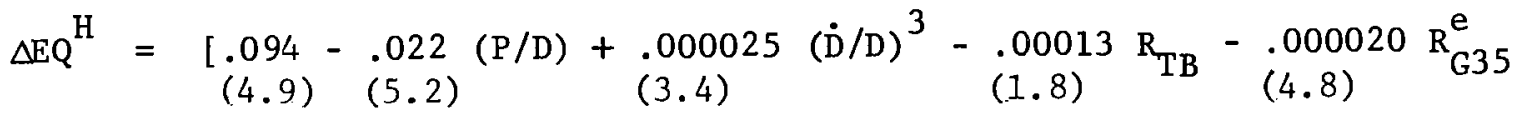

$$
\begin{aligned}
& -\underset{(5.0)}{.30 \mathrm{INCOME}} \mathrm{H} /\left(\mathrm{W}_{-1}^{\mathrm{H}}+\Delta \mathrm{W}^{\mathrm{H}}\right)-\underset{(2.4)}{(.000019} \mathrm{TAXDUMMY} \cdot \operatorname{SEAS} 4+\underset{(6.6)}{.000034} \text { SEAS4)(P/D)] }
\end{aligned}
$$

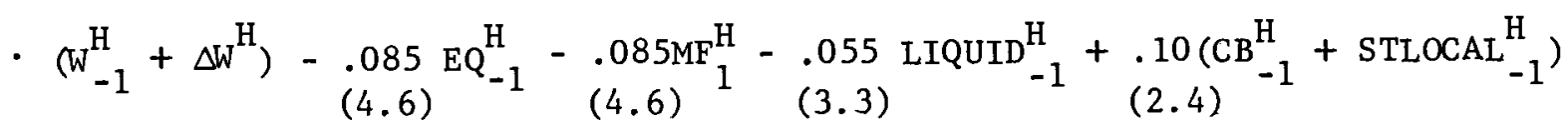

$$
\begin{aligned}
& +.043 \text { PENSION }_{-1}^{\mathrm{H}}
\end{aligned}
$$$$
\text { (3.2) }
$$

where $(\dot{D} / D))^{e} \equiv 100 \sum_{i=1}^{6} \delta_{i} \cdot\left(E_{-i} / E_{-}(i+1)-1\right), \sum \delta_{i}=1^{b}$

$$
\mathrm{R}_{\mathrm{G} 35}^{\mathrm{e}} \equiv \sum_{i=1}^{3} \omega_{i} \cdot\left[\mathrm{R}_{\mathrm{G} 35}+400\left(\mathrm{R}_{\mathrm{G} 35,-(i+1)} / \mathrm{R}_{\mathrm{G} 35,-i}-1\right)\right], \sum_{i} \omega_{i}=1^{\mathrm{b}}
$$

SAMPLE PERIOD: ${ }^{\mathrm{d}} 1960: 1-1976: 4$

$$
\mathrm{R}^{2}=.87 \mathrm{R}^{-2}=.83 \text { SER }=.518 \text { billion }\left(\mathrm{D}-\mathrm{W}=1.96, \mathrm{t}_{\mathrm{p}}=.09\right)
$$


Figure 2 (CONTINUED)

\section{Life Insurance Company Demand for Equities:}

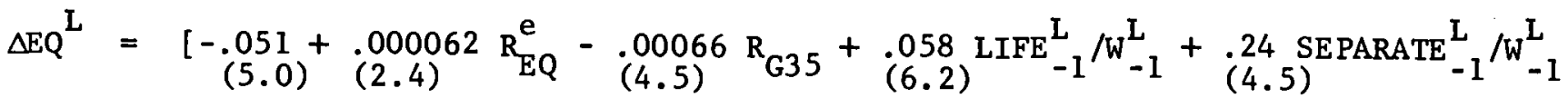

$$
\begin{aligned}
& \left.+\underset{(5.6)}{.15} \text { SURPLUS }_{-1}^{\mathrm{L}} / \mathrm{w}_{-1}^{\mathrm{L}}-\underset{(2.0)}{.00039} \operatorname{SEAS} 3\right] \cdot\left(\mathrm{w}_{-1}^{\mathrm{L}}\right)-\underset{(3.5)}{.11} \mathrm{EQ}_{-1}^{\mathrm{L}} \\
& -\underset{(2.1)}{.09 \operatorname{STLOCAL}_{-1}^{\mathrm{L}}}+\underset{(2.9)}{.28 \mathrm{MISC}_{-1}^{\mathrm{L}}}
\end{aligned}
$$

where $\quad R_{E Q}^{e} \equiv \sum_{i=1}^{12} \delta_{i} \cdot\left[(D / P)+400 \cdot\left(P_{-i} / P_{-(i+1)}-1\right)\right], \quad \sum \delta_{i}=1^{b}$

SAMPLE PERIOD: 1960:1 - 1976:4

$$
\begin{array}{llll}
\text { (Deflated) }^{\mathrm{e}} \mathrm{R}^{2}=.83 & \overline{\mathrm{R}}^{2}=.80 & \text { SER }=.00064 \quad\left(\mathrm{D}-\mathrm{W}=2.02, \mathrm{t}_{\rho}=-.03\right) \\
\text { (Undeflated) } & \mathrm{R}^{2}=.89 & \mathrm{R}^{2}=.86 & \text { SER }=.109 \mathrm{billion}
\end{array}
$$

4. Open-End Investment Company Demand for Equities:

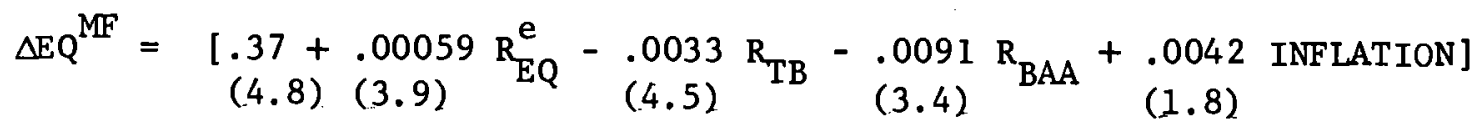

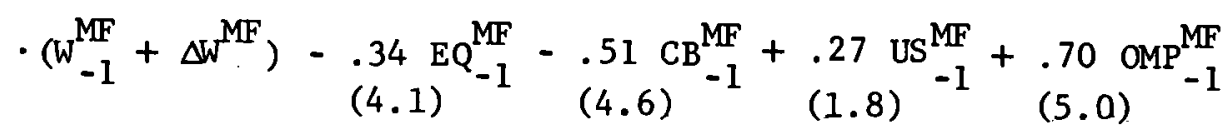

where $R_{E Q}^{e} \equiv \sum_{i=1}^{8} \delta_{i} \cdot\left[(D / P)+400 \cdot\left(P_{-1} / P-(i+1)-1\right)\right], \quad \sum_{i} \delta_{i}=1^{b}$

SAMPLE PERIOD: 1960:1 - 1976:4

(Deflated) $^{\mathrm{e}} \quad \mathrm{R}^{2}=.83 \quad \mathrm{R}^{2}=.80 \quad \mathrm{SER}=.0054 \quad\left(\mathrm{D}-\mathrm{W}=2.07, \mathrm{t}_{\rho}=-.65\right)$

(Undeflated) $^{\mathrm{f}} \quad \mathrm{R}^{2}=.83 \quad \mathrm{R}^{2}=.80 \quad$ SER $=.209$ billion

(Taking $\Delta W^{M F}$ from household mutual fund share equation:

$$
\mathrm{R}^{2}=.80 \quad \mathrm{R}^{2}=.76 \quad \mathrm{SER}=.226 \text { billion) }
$$


Figure 2 (CONTINUED)

5. Private Pension Fund Demand for Equities:

$$
\begin{aligned}
& \Delta E Q^{P}=\underset{(5.2)}{[.12+\underset{(3.8)}{.00012}} \mathrm{R}_{\mathrm{EQ}}^{\mathrm{e}}-\underset{(3.4)}{.0020} \mathrm{R} \mathrm{R}_{\mathrm{G} 35}+\underset{(5.4)}{.0025} \text { INFLATION }-\underset{(5.4)}{.010 \mathrm{ERISA}}
\end{aligned}
$$

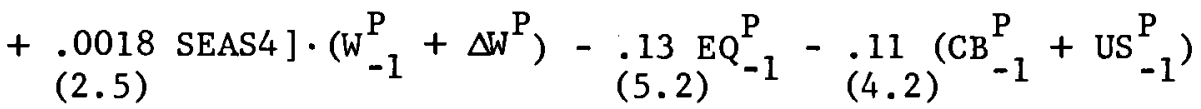

where $\mathrm{R}_{\mathrm{EQ}}^{\mathrm{e}} \equiv \sum_{i=1}^{6} \delta_{i} \cdot\left[(\mathrm{D} / \mathrm{P})+400 \cdot\left(\mathrm{P}_{-i} / \mathrm{P}_{-(i+1)}-1\right)\right], \sum_{i} \delta_{i}=1^{\mathrm{b}}$

SAMPLE PERIOD: ${ }^{\mathrm{g}}$ 1960:1 - 1976:4

(Deflated) $^{\mathrm{e}} \mathrm{R}^{2}=.66 \quad \mathrm{R}^{2}=.60 \quad \mathrm{SER}=.0022 \cdot \quad\left(\mathrm{D}-\mathrm{W}=1.91, t_{\rho}=.13\right)$ (Undeflated) ${ }^{\mathrm{f}} \mathrm{R}^{2}=.85 \quad \overline{\mathrm{R}}^{2}=.83 \quad$ SER $=.222$ billion

6. Property and Casualty Insurance Company Demand for Equities:

$$
\begin{aligned}
& \left.\Delta \mathrm{EQ}^{0}=\underset{(2.4)}{.25}{\left(\text { SURPLUS }^{0}\right)}^{\mathrm{e}}+\underset{(9.1)}{[.44}+\underset{(5.6)}{.00036} \mathrm{R}_{\mathrm{EQ}}^{\mathrm{e}}-\underset{(8.6)}{.0033} \mathrm{R}_{\mathrm{CP}}^{\mathrm{e}}+\underset{(2.6)}{.00098} \text { INFLATION }\right]
\end{aligned}
$$

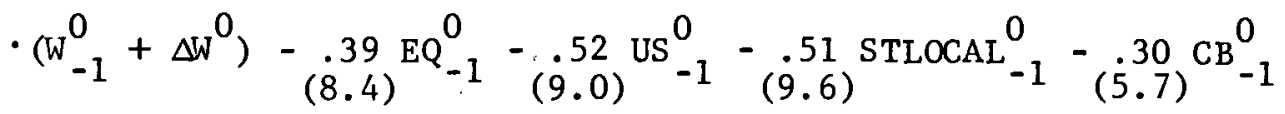

where $R_{C P}^{e} \equiv \sum_{i=1}^{6} \delta_{i} R_{C P,-(i+1)}, \quad \sum_{i} \delta_{i}=1^{b}$

$$
\begin{aligned}
& \mathrm{R}_{\mathrm{EQ}}^{\mathrm{e}} \equiv \sum_{i=1}^{10} \delta_{i} \cdot\left[(\mathrm{E} / \mathrm{P})+100 \cdot\left(E_{-i} / \mathrm{E}_{-(i+1)}-1\right)\right], \sum_{i} \delta_{i}=1^{\mathrm{b}} \\
& \text { (SURPLUS } \left.^{0}\right)^{\mathrm{e}} \equiv \sum_{i=1}^{5} \omega_{i} \cdot \operatorname{SURPLUS}_{-i+1}^{0}, \sum_{i} \omega_{i}=1^{b}
\end{aligned}
$$

SAMPLE PERIOD: 1960:1 - 1976: 4

(Deflated) $^{\text {e }} \quad R^{2}=.93 \quad \bar{R}^{2}=.92 . \quad$ SER $=.0014 \quad\left(D-W 1.97, \quad t_{\rho}=.16\right)$ (undeflated) ${ }^{\mathrm{f}} \mathrm{R}^{2}=.95 \quad \overline{\mathrm{R}}^{2}=.93 \quad$ SER $=.063$ billion 
Figure 2 (CONTINUED)

7. State and Local Government Retirement System Demand for Equities:

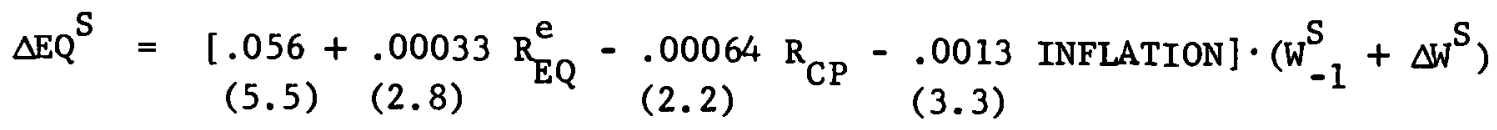

$$
\begin{aligned}
& \begin{array}{l}
.097 \mathrm{EQ}_{-1}^{\mathrm{S}}-.20 \mathrm{US}^{\mathrm{S}} \\
(3.1) \\
(4.5)
\end{array}
\end{aligned}
$$

where $R_{E Q}^{e} \equiv \sum_{i=1}^{10} \delta_{i} \cdot\left[(D / P)+400 \cdot\left(P_{-i} / P_{-(i+1)}-1\right)\right], \sum_{i} \delta_{i}=1^{b}$

SAMPLE PERIOD: 1966:1 - 1976:4

$$
\mathrm{R}^{2}=.73 \quad \mathrm{R}^{2}=.68 \quad \mathrm{SER}=.174 \text { billion }\left(\mathrm{D}-\mathrm{W}=1.75, \mathrm{t}_{\rho}=.67\right)
$$

NOTES:

a Numbers in parentheses are asymptotic t-statistics. The $R^{2}$ is the coefficient of determination, $\vec{R}^{2}$ is the coefficient of determination adjusted for degrees of freedom, SER is the standard error of the regression, $D-W$ is the Durbin-Watson statistic and $t_{p}$ is the Wald test statistic for first order serial correlation of the residuals. The statistic $t_{p}$ is asymptotically distributed as a $t$-statistic under the null hypothesis that the residuals do not display serial correlation. All equations are estimated using the Brundy-Jorgenson instrumental variable technique described in the text.

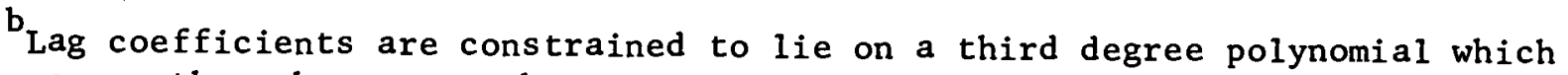
passes through zero at the maximum lag length " $i$." The sum of the lag coefficients is constrained to equal unity.

${ }^{c}$ A time dummy variable was included for $1970: 3$, the quarter following the Penn Central collapse.

${ }^{d}$ A time dummy variable was included for 1962:2. Households were inexplicably very large net sellers of equity in this quarter.

The sample period for this regression differs from that used in the other regressions because of major changes that occurred in state laws governing the investment practices of these institutions around 1966. 
Figure 3

ESTIMATED EQUITY SUPPLY EQUATION FOR NON-FINANCIAL CORPORATIONS $^{\mathrm{a}}$

8. Gross Equity Issues by Domestic Non-Financia1 Corporations:

$$
\begin{aligned}
& \Delta \mathrm{EQ}_{\mathrm{S}}^{\mathrm{N}}=-.14\left(\Delta \text { WORKING } \text { CAPITAL }^{\mathrm{N}}\right)^{\mathrm{e}}+\left[.056+.020(\mathrm{P} / \mathrm{D})+.00060 \mathrm{R}_{\mathrm{BAA}}\right. \\
& \text { (3.0) (6.3) (9.7) (6.3) } \\
& \left.-.0000057(\dot{\mathrm{R}} / \mathrm{R})^{\mathrm{e}}\right] \cdot\left(\mathrm{D}_{-1}^{\mathrm{N}}+\Delta \mathrm{D}^{\mathrm{N}}\right)-.065 \text { SURPLUS }_{-1}^{\mathrm{N}}-.065 \text { LONG } \mathrm{DEBT}_{-1}^{\mathrm{N}}
\end{aligned}
$$

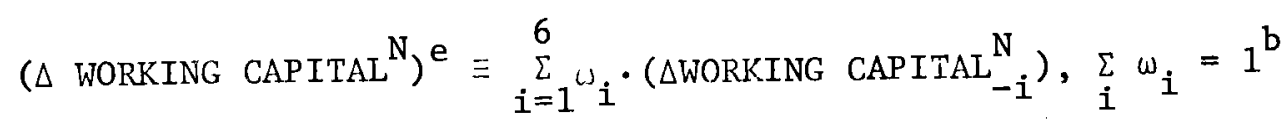

$$
(\dot{R} / R)^{e} \equiv 400 \sum_{1=0}^{2} \delta_{i} \cdot\left(R_{C P, i} / R_{C P,-(i+1)}-1\right), \sum_{i} \delta_{i}=1^{b}
$$

SAMPLE PERIOD: $1960: 1-1976: 4$

$$
\mathrm{R}^{2}=.92 \overline{\mathrm{R}}^{2}=.90 \mathrm{SER}=.353 \text { billion }\left(\mathrm{D}-\mathrm{W}=1.77, \mathrm{t}_{\mathrm{p}}=.82\right)
$$

NOTES:

${ }^{a}$ Numbers in parentheses are asymptotic t-statistics. For other regression summary statistics, see note (a) of the preceding exhibit.

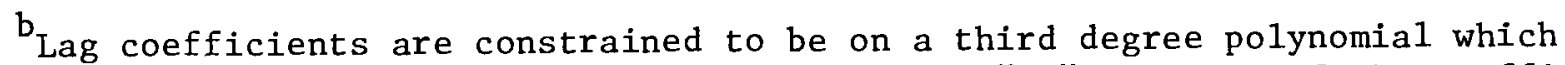
passes through zero at the maximum lag length "i." The sum of the coefficients is constrained to equal unity. 
Figure 4

\section{VARIABLE DEFINITIONS}

$\mathrm{CB}$

D

$D^{N}$

$\Delta D^{N}$

E

EQ

$\triangle \mathrm{EQ}$

$\triangle \mathrm{EQ}_{\mathrm{S}}^{\mathrm{N}}$

ERISA.

INCOME $^{\mathrm{H}}$

INFLATION

LIFE ${ }^{\mathrm{L}}$

LIQUID ${ }^{\mathrm{H}}$.

LONG DEBT ${ }^{\mathrm{N}}$

MISC $^{\mathrm{L}}$
Holdings of corporate and foreign bonds.

Standard and Poor's index of dividends per share.

Replacement value of capital stock of U.S. nonfinancial corporations plus holdings of financial assets.

Net funds raised in financlal markets plus gross equity retirements of nonfinancial corporations.

Standard and Poor's index of earnings per share.

Holdings of equities.

Net acquisitions of equities.

Gross equity issues by domestic nonfinancial corporations.

Time dummy for Employee Retirement Income Security Act of 1974. Equal to 0 before and 1 from 1974:3 to $1976: 4$.

Gross personal income of households (quarterly rate).

Proxy for expected inflation. Equal to a thirteen quarter moving average of current and past rates of inflation.

Life insurance reserves at life insurance companies.

Household holdings of liquid assets. Equal to household holdings of U.S. government securities, openmarket paper, time deposits and savings accounts, and money market fund shares.

Long-term debt of nonfinancial corporations.

Miscellaneous assets of life insurance companies (primarily receivables). 
Figure 4 (CONTINUED)

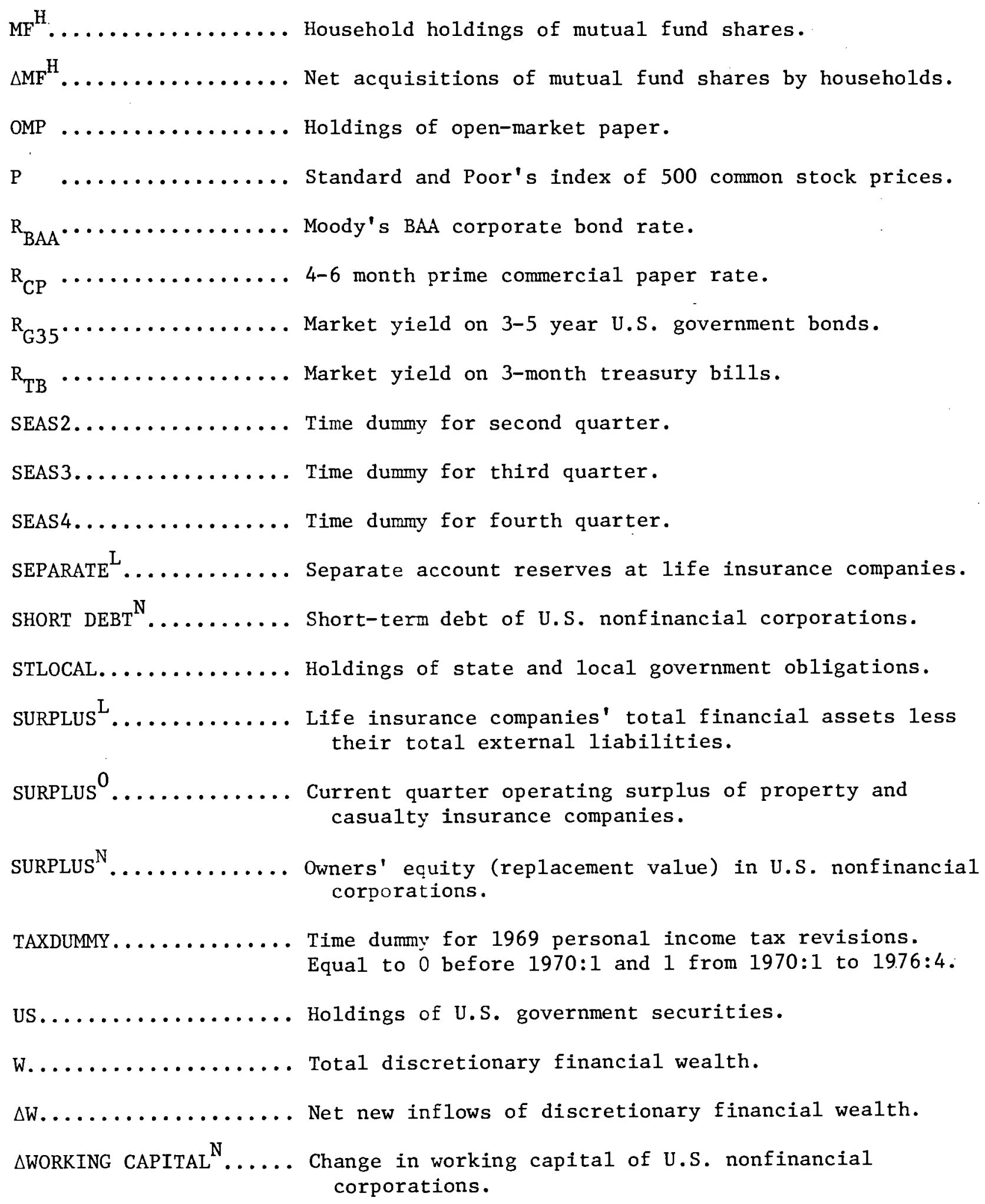


of the mutual fund sector are held in the form of long-term corporate bonds, $15 \%$ at year-end 1976. Consequently, the long-term bond yield is in effect one component of the total yield on new mutual fund assets. The positive coefficient associated with the long-term bond rate in regression (1) may reflect the fact that mutual funds are a vehicle by which investors invest in long-term bonds.

The TAXDUMMY variable is an attempt to measure the impact on households' demands for mutual fund shares of the 1969 individual income tax revisions. These revisions substantially increased the effective capital gains tax rates paid by high income investors. The negative coefficient associated with the TAXDUMMY variable suggests that this tax code change has reduced the demand for mutual fund shares by households.

Regression (1) implies that $9.7 \%$ of the discrepancy between desired and actual mutual fund share holdings are removed by households within a single quarter.

Household demand for equities. The demand for directly held equities by households is seen to be positively related to the current dividend/price ratio and the expected rate of growth of dividends per share. This demand is negatively related to the three month treasury bill rate and the expected rate of return on three-five year U.S. government bonds.

The INCOME variable in the household equity eqution is the logical counterpart to the transactions demand for money. The negative coefficient associated with this variable in regression (2) indicates a negative transactions demand for equities. Similar results have been reported by Hendershott (1977). 
A fourth quarter seasonal dummy is included in the household equity regression in an attempt to verify the claim that households sell off equities in the fourth quarter for income tax reasons. ${ }^{11}$ In the fourth quarter there is an incentive for individuals to reduce their taxable income by selling securities on which they have accrued unrealized capital losses. This incentive is higher (a) the higher were the individuals' realized capital gains during the year and (b) the higher is the individuals' capital gains tax rate. For these reasons, the fourth quarter seasonal dummy is weighted by the inverse of the dividend/price ratio, to reflect (a), and a separate seasonal dummy is included for the post 1969 tax code revision period, to reflect (b). 12

Regression 2 indicates that the fourth quarter sell-off of equities is important and has been more pronounced in the period after the 1969 tax code revisions. Moreover, the reported regression has a lower standard error than an alternative regression in which the seasonal factors were not weighted by the inverse of the dividend/price ratio. Surprisingly, no effect of the 1969 tax code revision was discernable for the first, second or third quarters.

Regression (2) implies that $8.5 \%$ of the discrepancy between desired and actual household equity holdings are removed in a single quarter.

\section{Life insurance company demand for equities. The estimated short-} run demand for equities by life insurance companies is positively related to the expected yield on equities and negatively to the yield to maturity on three-five year U.S. government bonds. The absence of any short-term interest rate in this equation is not especially surprising in view of the long-term nature of life insurance companies' liabilities. 
The equity demand equation for life insurance companies includes three institutional variables thought to play an important role in the portfolio behavior of these institutions. These additional variables are life insurance reserves, separate pension fund account reserves and owners' equity as fractions of total 'financial assets. ${ }^{13}$

Life insurance companies' investments of life insurance reserves are highly restricted by state regulatory authorities. In particular, the fraction of these reserves invested in equities has been legally restricted to well under $10 \%$ in most states throughout our sample period. Separate pension fund account reserves, on the other hand, are virtually unrestricted in most states. Consequently, the proportion of separate account reserves invested in equities has tended to be quite high. From their inception in 1967 through 1976, equities have comprised between 63\% and $86 \%$ of the value of separate account reserves. In terms of restrictions on their use, life insurance general funds fall somewhere between life insurance and separate account reserves.

The above considerations suggest that the composition of life insurance companies' liabilities is an important influence on their portfolio behavior. Our empirical results tend to confirm this conjecture. The three liability variables are highly significant as explanators of life insurance company equity demands. Moreover, the values of their coefficients are very much in line with our prior expectations. Net acquisitions of equities tend to be greatest out of separate account reserves followed by owner's equity and life insurance reserves. Regression (3) indicates that $11 \%$ of any undesired equity holdings are removed by life insurance companies within a single quarter. 
Open-end investment company demand for equities. The demand for equities by this group is seen to be positively related to the own yield on equities and negatively related to both short-term and long-term interest rates. Increases in expected inflation appear to increase the demand for equities by mutual funds; however, the significance of this effect is marginal.

The estimated speed of adjustment of actual to desired equity holdings is quite large, $34 \%$ per quarter. This is consistent with the we11 known fact that this group of institutions has the highest equity portfolio turnover rate of any of the major institutional investors.

Private pension fund demand for equities. This sector's short-run demand for equities is related positively to the expected yield on equities and negatively to the three-five year U.S. government bond rate. The absence of any effect of short-term interest rates is not surprising given the long term nature of this sector's liabilities. Private pension fund equity demands also appear to be strongly affected by the expected rate of inflation: increases in expected inflation tending to increase the demand for equities.

The ERISA variable in regression (5) is a time dummy relfecting congressional passage of the Employee Retirement Income Security Act of 1974 . The coefficient associated with this variable is negative and highly significant, suggesting that the passage of this legislation has tended to reduce the equity demands of private pension funds.

The speed of adjustment of actual to desired equity holding implied by regression (5) is $13 \%$ per quarter. 
Property and casualty insurance company demand for equities.

Regression (6) indicates that this sector's short-run equity demands are positively related to the expected equity yield and negatively related to the expected yield associated with rolling over short-term commercial paper holdings $\mathrm{R}_{\mathrm{CP}}^{\mathrm{e}}$. Increases in expected inflation are seen to increase this sector's equity demands.

The $\left(\text { SURPLUS }^{0}\right)^{\mathrm{e}}$ variable in regression (6) is intended to reflect expected underwriting income. The regression implies that a $\$ 1.00$ increase in expected quarterly earnings gives rise to a $\$ .25$ increase in quarterly net acquisitions of equities.

The speed of adjustment implied by this equation is $39 \%$ per quarter. While seemingly large, this speed of adjustment is comparable to that reported by Friedman and Roley (1978) for this sector's corporate bond demands.

State and local government retirement system demand for equities. This sector's short-run demand for equities is positively related to the expected own yield on equities and negatively related to the three-six month commercial paper rate and expected inflation. The speed of adjustment of this sector's actual to desired equity holdings is estimated to be $9.7 \%$ per quarter.

Gross equity issues by domestic nonfinancial corporations. The regression equation for gross eçuity issues by domestic nonfinancial corporations appears in Figure 3. Gross equity issues are seen to respond negatively to the Standard and Poor's dividend/price ratio and positively to the level of long-term interest rates. This equation also implies that gross equity issues fall when interest rates are expected to rise. 
It is sometimes argued that firms attempt to match the maturity structure of their liabilities with that of their assets. That is, firms try to finance long-term assets with long term liabilities and short term assets with short-term liabilities. The working capital variable in the equity supply equation is an attempt to capture this effect. This variable is intended to represent firms' expectations about future increases in working capital requirements. To the extent that changes in working capital are initially considered temporary this variable should be negatively related to current equity issues.

This prior belief is supported by regression (1) in Figure 3 . Increases, in expected working capital requirements, holding constant the current level of net funds raised in financial markets, tend to depress gross equity issues.

The coefficient of lagged owner's equity in the equity supply equation is only -.065 , implying that only $6.5 \%$ of the discrepancy between the desired and actual levels of owner's equity is removed in any given quarter by floating new equity issues. This speed-of-adjustment is considerably smaller than the speeds of adjustment which characterize the equity demand equations in Figure 2. There are two possible explanations for this result. First, owner's equity can be increased by retaining earnings as we11 as by issuing new shares. The $6.5 \%$ figure cited above reflects only the propensity to raise new owner's equity by this latter route. Generally, raising new equity by issuing new shares is viewed as more expensive in the eyes of management than raising the funds through retained earnings. Thus, the total proportion of the discrepancy between desired and actual owner's equity removed in a single quarter may be substantially larger than $6.5 \%$. 
Second, the slow speed-of-adjustment cited above may simply reflect the higher costs associated with restructuring a firm's liabilities relative to the costs incurred by investors in restructuring their asset portfolios. Registration fees and other floatation costs associated with public offerings of new equities normally amount to about $10 \%$ of the net proceeds, rendering new equity issues a very expensive financing instrument. Call provisions also normally make the refinancing of long term bond issues an unattractive alternative.

Summary of equity demand/supply regression. On the whole, the explanatory powers of these regressions are quite good. In terms of the undeflated dependent variables, the $\bar{R}^{2}$ of these regressions vary between .68 for state and local government retirement systems to .92 for the equity demands of property and casualty insurance companies. The remainder of the structural equations exhibit $\overline{\mathrm{R}}^{2}$ roughly between .80 and .90 .

The regression standard errors are also quite respectable, being largest in the household equity equation. This is not surprising in view of the fact that this sector is a residual in the flow-of-funds accounts. Serial correlation does not appear to be a major problem in the structural equation regressions. While the Durbin-Watson statistics are reported for comparison purposes, the standard test based on this statistic is not valid for the problem at hand. The $t_{p}$ test for first order serial correlation described at the end of Figure 2, however, is a valid test. In no case is this test statistic significant at the $10 \%$ level. 
V. The Structural Equity Market Model

The structural model of the U.S. equity market is summarized in Figure 5. It is made up of the eight structural equations estimated in Section IV, ten accounting identities, a market clearing identity and nine bridge equations. All told, there are twenty-eight equations in the model and an equal number of endogenous variables. To facilitate the exposition, in Figure 5 the exogenous variables are written in lower case letters while the endogenous variables are written in upper case.

The core of the equity market model consists of equations (1) - (11). The first eight equations are the structural demand and supply equations estimated and discussed above. The accounting identity (9) notes the fact that the net acquisition of financial assets by mutual funds is, by definition, equal to their current surplus plus the net acquisition of mutual fund shares by households. Household net acquisitions of mutual fund shares are endogenously determined from equation (1). Mutual funds' current surplus is approximated by the bridge equation (1) which is displayed in detail in Figure 6. This surplus is high1y negatively correlated with lagged percentage changes in $P$, the Standard and Poor's stock price index.

The market clearing identity (11) imposes the short-run equilibrium requirement that the market net excess flow demand for equities equals zero. Net equity demands and supplies by sectors not explicitly modeled in Section IV (i.e., $\Delta e q^{e x o g}$ and $\Delta e q_{S}^{e x o g}$ respectively) are treated as exogenously given in this study. These exogenous flows consist of the net acquisitions of equities by foreigners, domestic banks and security brokers and dealers and the net equity issues in the U.S. by foreign corporations and domestic financial corporations. 14 


\section{Figure 5}

\section{THE U.S. EQUITY MARKET MODEL ${ }^{a}$}

(1) $\Delta \mathrm{MF}^{\mathrm{H}}=\mathrm{g}^{\mathrm{H}}\left[\mathrm{P}, \Delta \mathrm{w}^{\mathrm{H}}, \mathrm{w}_{-\mathrm{I}}^{\mathrm{H}}, \mathrm{d}, \mathrm{d}_{-1}, \ldots, \mathrm{d}_{-4}, \mathrm{r}_{\mathrm{CP}}, \mathrm{r}_{\mathrm{BAA}}\right.$, inflation, taxdummy, seas 2 , seas $3, \mathrm{MF}_{-1}^{\mathrm{H}}, \mathrm{EQ}_{-1}^{\mathrm{H}} \cdot$ stlocal ${ }_{-1}^{4}$ ]

(2) $\Delta E Q^{H}=f^{H}\left[P, \Delta w^{H}, w_{-1}^{H}, d, e_{-1}, \ldots, e_{-8}, r_{T B}, r_{G 35}, r_{G 35,-1}\right.$, $r_{G 35,-2}, r_{G 35,-3}$, income, taxdummy, seas4, $\mathrm{EQ}_{-1}^{\mathrm{H}}, \mathrm{MF}_{-1}^{\mathrm{H}}$, stlocal ${ }_{-I}^{\mathrm{H}}, \mathrm{cb}_{-\mathrm{I}}^{\mathrm{H}}$, liquid ${ }_{-\mathrm{I}}^{\mathrm{H}}$, PENSION $\left._{-\mathrm{I}}^{\mathrm{H}}\right]$.

(3) $\Delta E Q^{L}=f^{L}\left[P, P_{-1}, \ldots, P_{12}, \Delta w^{L}, w_{-1}^{L}, d, r_{G 35}\right.$, seas4, life $e_{-1}^{L}$, $\left.\operatorname{SEPARATE}_{-1}^{\mathrm{L}}, \operatorname{SURPLUS}_{-1}^{\mathrm{L}}, \mathrm{EQ}_{-1}^{\mathrm{L}}, \mathrm{stlocal}_{-1}^{\mathrm{L}}, \mathrm{misc}_{-1}^{\mathrm{L}}\right]$

(4) $\Delta E Q^{M F}=f^{M F}\left[P, P_{-1}, \ldots, P_{-8}, \Delta W^{M F}, W_{-1}^{M F}, d, r_{T B}, r_{B A A}\right.$, inflation, $\left.E Q_{-1}^{M F}, \quad c b_{-1}^{M F}, u s_{-1}^{M F}, \quad o m p_{-1}^{M F}\right]$

(5) $\Delta E Q^{P}=f^{P}\left[P, P_{-1}, \ldots, P_{-6}, \Delta w^{P}, w_{-1}^{P}, d, r_{G 35}\right.$, inflation, erisa, seas4,. $\left.E Q_{-1}^{P}, c b_{-1}^{P}, u_{-1}^{P}\right]$

(6) $\Delta E Q^{0}=f^{0}\left[P, \Delta w^{0}, w_{-1}^{0}, e, e_{-1}, \ldots, e_{-5}\right.$, inflation, $\Delta$ surplus ${ }^{0}$, $\Delta$ surplus $_{-1}^{0}, \ldots, \Delta$ surplus $_{-4}^{0}, \mathrm{EQ}_{-1}^{0}$, stlocal $\left.{ }_{-1}^{0}, \mathrm{cb}_{-1}^{0}, \mathrm{us}_{-1}^{0}\right]$

(7) $\Delta E Q S=f^{S}\left[P, P_{-I}, \ldots, P_{-4}, \Delta w, w_{-1}^{S}, d, r_{C P}\right.$, inflation, $E Q_{-1}^{S}$,

(8)

$$
\begin{aligned}
& \left.S_{-1}^{S}\right] \\
& \Delta E Q_{S}^{N}=h^{N}\left[P, \Delta d^{N}, d_{-1}^{N}, d, r_{B A A}, r_{C P}, r_{C P,-1}, \ldots, r_{C P,-3}\right. \text {, } \\
& \Delta \text { working capital }{ }^{N}, \Delta \text { working capital }{ }_{-1}^{N}, \ldots, \Delta \text { working } \\
& \operatorname{capital}_{-4}^{\mathrm{N}} \text {, networth }{ }_{-1}^{\mathrm{N}} \text {, long-term debt }{ }_{-1}^{\mathrm{N}} \text {, short-term } \operatorname{debt}_{-1}^{\mathrm{N}} \text { ] } \\
& \text { - equity retirements }{ }^{N_{1}}
\end{aligned}
$$


Figure 5 (CONTINUED)

(9) $\Delta W^{M F}=\Delta$ SURPLUS ${ }^{M F}+\Delta \mathrm{MF}^{\mathrm{H}}$

(10) $\quad \Delta$ SURPLUS $^{\mathrm{MF}}=\mathrm{q}\left[\mathrm{P}_{-1}, \ldots, \mathrm{P}_{-10}, \mathrm{~W}_{-1}^{\mathrm{MF}}\right.$, seas 2 , seas $\left.3, \mathrm{EQ}_{-2}^{\mathrm{MF}}, \ldots, \mathrm{EQ}_{-12}^{\mathrm{MF}}\right]$

(11) $\Delta E Q^{H}+\Delta E Q^{L}+\Delta E Q^{M F}+\Delta E Q^{P}+\Delta E Q^{0}+\Delta E Q^{S}+\Delta e q^{e x o g} \equiv \Delta E Q_{S}^{N}+\Delta e q_{S}^{e x o g}$

(12) $\mathrm{EQ}^{\mathrm{H}}=\operatorname{beta}^{\mathrm{H}} \cdot(\mathrm{P} / \mathrm{P}-1) \cdot\left(\mathrm{EQ}_{-1}^{\mathrm{H}}+\Delta \mathrm{EQ}^{\mathrm{H}}\right)$

(13) $\quad \mathrm{EQ}^{\mathrm{L}}=\operatorname{beta}^{\mathrm{L}} \cdot\left(\mathrm{P} / \mathrm{P}_{-1}\right) \cdot\left(\mathrm{EQ}_{-1}^{\mathrm{L}}+\Delta \mathrm{EQ}^{\mathrm{L}}\right)$

(14) $\quad \mathrm{EQ}^{\mathrm{MF}}=$ beta $\mathrm{MF} \cdot\left(\mathrm{P} / \mathrm{P}_{-1}\right) \cdot\left(\mathrm{EQ}_{-1}^{\mathrm{MF}}+\Delta E \mathrm{Q}^{\mathrm{MF}}\right)$

(15) $\mathrm{EQ}^{\mathrm{P}}=\operatorname{beta}{ }^{\mathrm{P}} \cdot(\mathrm{P} / \mathrm{P}-1) \cdot\left(\mathrm{EQ}_{-1}^{\mathrm{P}}+\Delta \mathrm{EQ}^{\mathrm{P}}\right)$

(16) $\mathrm{EQ}^{0}=\operatorname{beta}^{0} \cdot\left(\mathrm{P} / \mathrm{P}_{-1}\right) \cdot\left(E Q_{-I}^{0}+\Delta E Q^{0}\right)$

(17) $\mathrm{EQ}^{\mathrm{S}}=$ beta $^{\mathrm{S}} \cdot\left(\mathrm{P} / \mathrm{P}_{-1}\right) \cdot\left(E Q_{-1}^{\mathrm{S}}+\Delta E \mathrm{Q}^{\mathrm{S}}\right)$

(18) $\mathrm{W}^{\mathrm{L}} \equiv \mathrm{EQ}^{\mathrm{L}}+$ other assets ${ }^{\mathrm{L}}$

(19) $\mathrm{W}^{\mathrm{MF}} \equiv \mathrm{EQ}^{\mathrm{MF}}+$ other assets $^{\mathrm{MF}}$

(20) $\mathrm{W}^{\mathrm{P}} \equiv \mathrm{EQ}^{\mathrm{P}}+$ other assets $^{\mathrm{P}}$

(21) $\mathrm{W}^{0} \equiv \mathrm{EQ}^{0}+$ other assets ${ }^{0}$

(22) $\mathrm{W}^{\mathrm{S}} \equiv \mathrm{EQ}^{\mathrm{S}}+$ other assets $\mathrm{S}^{\mathrm{S}}$

(23) $\mathrm{MF}^{\mathrm{H}} \equiv \mathrm{W}^{\mathrm{MF}}$

(24) PENSION $^{\mathrm{L}}=$ alpha $\cdot \mathrm{W}^{\mathrm{L}}$

(25) SEPARATE ${ }^{\mathrm{L}}=$ gamma $\cdot \mathrm{W}^{\mathrm{L}}$

(26) SURPLUS $^{L}=W^{L}-$ PENSION $^{L}-1$ life $^{L}$ - other liabilities ${ }^{L}$

(27) PENSION ${ }^{\mathrm{H}} \equiv$ PENSION ${ }^{\mathrm{L}}+\mathrm{W}^{\mathrm{P}}+\mathrm{W}^{\mathrm{S}}+$ pension exog 
Figure 5 (CONTINUED)

(28)

$W^{H} \equiv E Q^{H}+M^{H}+$ PENSION ${ }^{H}+$ life ${ }^{L}+$ other assets $^{H}$

NOTES :

${ }^{a}$ It is important to bear in mind that the notation $\triangle M F$ and $\triangle E Q$ denotes net acquisitions of mutual fund shares and equities respectively. These quantities differ from the changes in the actual holdings of these assets by the amount of unrealized capital gains accruing during the quarter. Changes in actual holdings can be inferred from equations (12) - (17), (19) and (23). The author regrets this confusing notation.

To facilitate reading this table all exogenous variables are written in lower case lettering while endogenous variables are written in upper case. 
Figure 6

BRIDGE EQUATION FOR $\triangle$ SURPLUS $^{\text {MF }^{a}}$

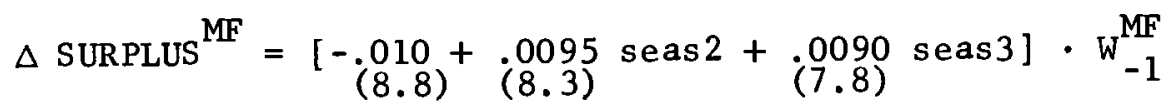

$$
\begin{aligned}
& +\sum_{i=0}^{-8} \delta_{i} \cdot\left[\left(P_{i-1} / P_{i-2}-1\right) \cdot \mathrm{EQ}_{i-2}^{\mathrm{MF}}\right]+.47 \tilde{U}_{-1} \\
& \delta_{0}=-.024^{\mathrm{b}} \quad \delta_{5}=-.015 \\
& \text { (2.1) (2.5) } \\
& \delta_{1}=-.015 \quad \delta_{6}=-.018 \\
& \text { (2.3) (2.6) } \\
& \delta_{2}=-.011 \quad \delta_{7}=-.018 \\
& \text { (1.7) (2.7) } \\
& \delta_{3}=-.010 \quad \delta_{8}=-.016 \\
& \delta_{4}=-.012 \\
& \text { (2.3) }
\end{aligned}
$$

SAMPLE PERIOD: 1960:1 - 1976:4

$$
\mathrm{R}^{2}=.62 \quad \mathrm{R}^{2}=.58 \quad \mathrm{SER}=.174 \quad \text { D.W. }=1.93
$$

NOTES :

$a_{\text {The estimation method is GLS and the estimated autoregression (rho) }}$ coefficient is .47

$b_{\text {The }}\left\{\delta_{i}\right\}$ are constrained to lie on a third degree polynomial. 
Equations (12) - (28) generate the endogenous variables which when lagged appear as arguments in (1) - (10). Relations (12) - (17) relate the capital gains on investor groups' equity holdings to that on the Standard and Poor's stock price index P. The exogenous weighting factors beta ${ }^{(i)}$ are set equal to the actual historical values of the quantities $\left[E Q{ }^{(i)} /\left(E Q_{-1}^{(i)}+\Delta E Q{ }^{(i)}\right)\right] \cdot\left(P / P_{-1}\right)$ in dynamic simulations of the equity market model. No attempt was made to explain the variation of the "beta" factors over time because of data problems associated with the flow-of-funds equity level series. ${ }^{15}$

The accounting identities (18) - (22) relate the total financial asset holdings of the institutional investors to the value of their equity and non-equity holdings. Non-equity asset holdings are treated as exogenous in the model.

Identity (23) equates the value of households' holdings of mutual fund shares to the value of the assets held by mutual funds.

The bridge equations (24) and (25) relate the pension and separate account reserves of life insurance companies to the level of their total financial assets. The simulated ratios $\operatorname{PENSION}^{\mathrm{L}} / \mathrm{W}^{\mathrm{L}}$ and SEPARATE ${ }^{L} / \mathrm{W}^{\mathrm{L}}$ are constrained to equal the historical values of these quantities.

Relation (26) defines the financial surplus of life insurance companies to be their total financial assets less the sum of pension reserves, life insurance reserves and other liabilities.

Equation (27) is an accounting identity which stipulates that households' pension reserves are equal to the total financial assets of private and state and local pension funds plus the pension reserves of life insurance companies and pension liabilities of other (exogenous) sectors. This latter quantity consists largely of pension liabilities of the federal government. The final equation, (28), is simply the 
wealth identity for the household sector.

Model validation experiments. To assess the validity and consistency of the above structural equity market model, three historical tracking experiments are performed. Two of these are within-sample tracking tests while the third is the out-of-sample tracking exercise.

The first validation experiment involves comparing a within-sample (1960:1 - 1976:4) static simulation of the model's stock price variable P with its actual historical record over the period. Simulated versus actual values of $\log [\mathrm{P}]$ together with the associated simulation errors and statistics are presented in Figures $7-8 .{ }^{16}$

As can be seen from these plots, the model tracks historical stock prices equally as well over the second half of the sample period as it does over the first half, even though stock prices are more volatile over the second half.

The mean simulation errors for both $\mathrm{P}$ and $\log [\mathrm{P}]$ are very small. Their associated RMSEs are 3.2 and .040 respectively. Some serial correlation is evident in the simulation residuals with the Durbin-Watson statistics being 1.66 and 1.60 respectively.

These static simulation results compare quite favorably with those reported by Modigliani and Cohn. They report a RMSE of .042 and a DurbinWatson statistic of 1.54 for their regression of $\log$ [P] "with error feedback."

Although our sample periods differ somewhat, the closeness of Modigliani and Cohn's and our own static simulation RMSEs and Durbin-Watson statistics is remarkable. This is even more striking in view of the fact that their estimation procedure (GLS) essentially acts to minimize their within- 


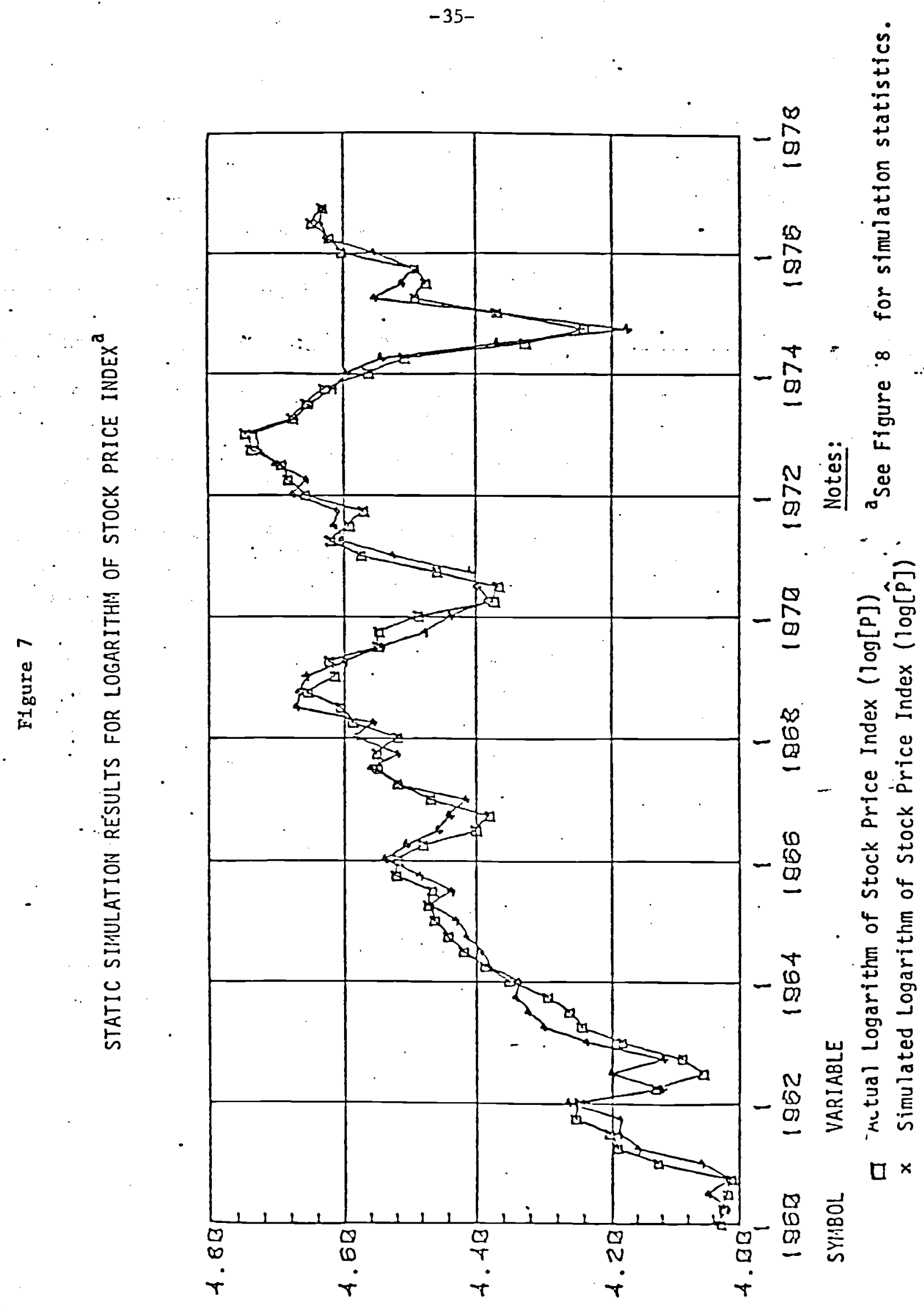




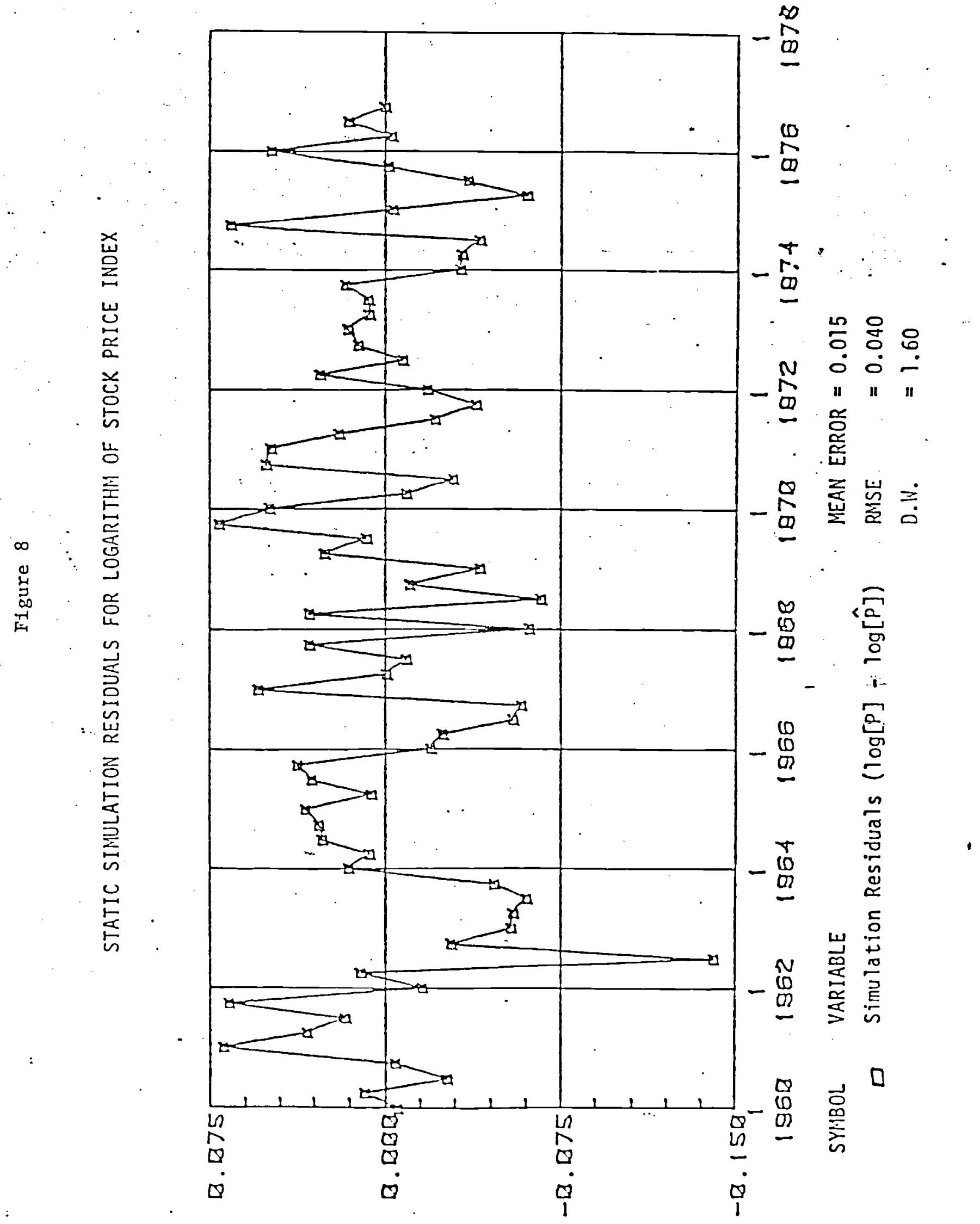


sample static simulation RMSE whereas our structural estimation approach does not directly focus on this criterion.

A more useful performance test relates to the model's ability to track stock prices in a fully dynamic simulation. 17 Actual and simulated values for this exercise are presented in Figures 9-10. As these diagrams show, the structural equity market model again tracks the historical values of $\mathrm{P}$ quite well over the sample period. The mean simulation errors for $\mathrm{P}$ and $\log [P]$ are small and their associate RMSEs are 4.3 and .053 respectively. The residual plot in Figure 10 indicates substantial serial correlation between successive simulation errors. The Durbin-Watson statistics associated with the errors for $P$ and $\log [P]$ are .76 and .74 respectively, implying serial correlation coefficients of approximately .62 and .63 respectively.

In their reduced-form regression for $\log [P]$ "without feedback," Modigliani and Cohn report a regression standard error of .063 . This is comparable to our own RMSE for $\log [\mathrm{P}]$ of .053 . Their estimated autoregression coefficient of .74 in this model is also of the same order of magnitude as our own .63 . Thus, again, the structural equity market model compares quite favorably with the Modigliani and Cohn's reduced-form model in terms of within sample forecasting accuracy.

Modigliani and Cohn also estimate an equation for $\log [\mathrm{P}]$ in $\mathrm{f}$ irst differenced form. This eliminates most of their residual correlation and yields a standard error of the regression for $\log [\mathrm{P}]$ of .044 .

In Figure 11 we have plotted the historical values of $\Delta \log [P]$ together with those implied by the dynamic control simulation discussed above. The simulation RMSEs for $\Delta P$ and $\Delta \log [P]$ are 3.8 and .046 respectively while the associated Durbin-Watson statistics are 1.92 and 1.99 . Our results and 







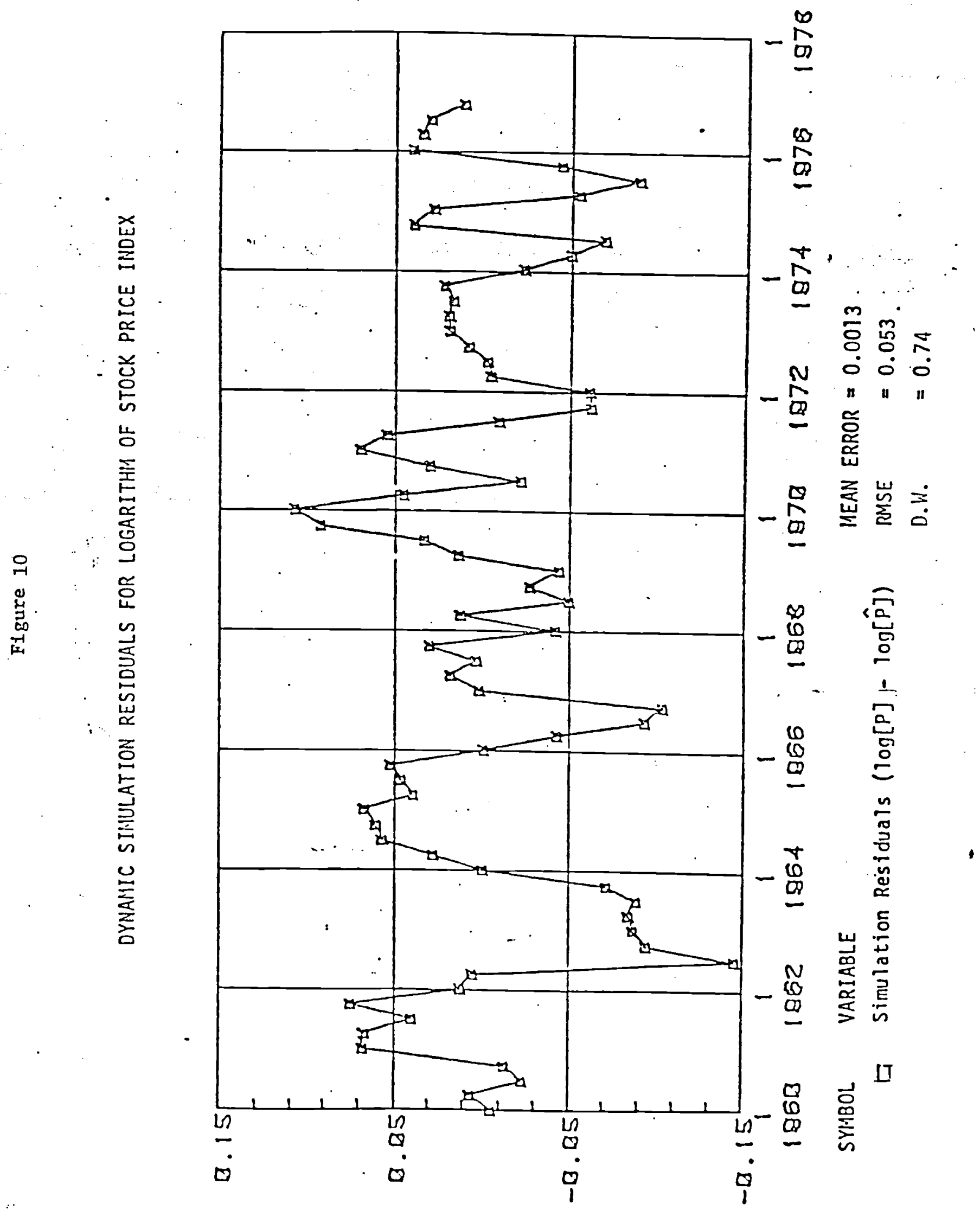



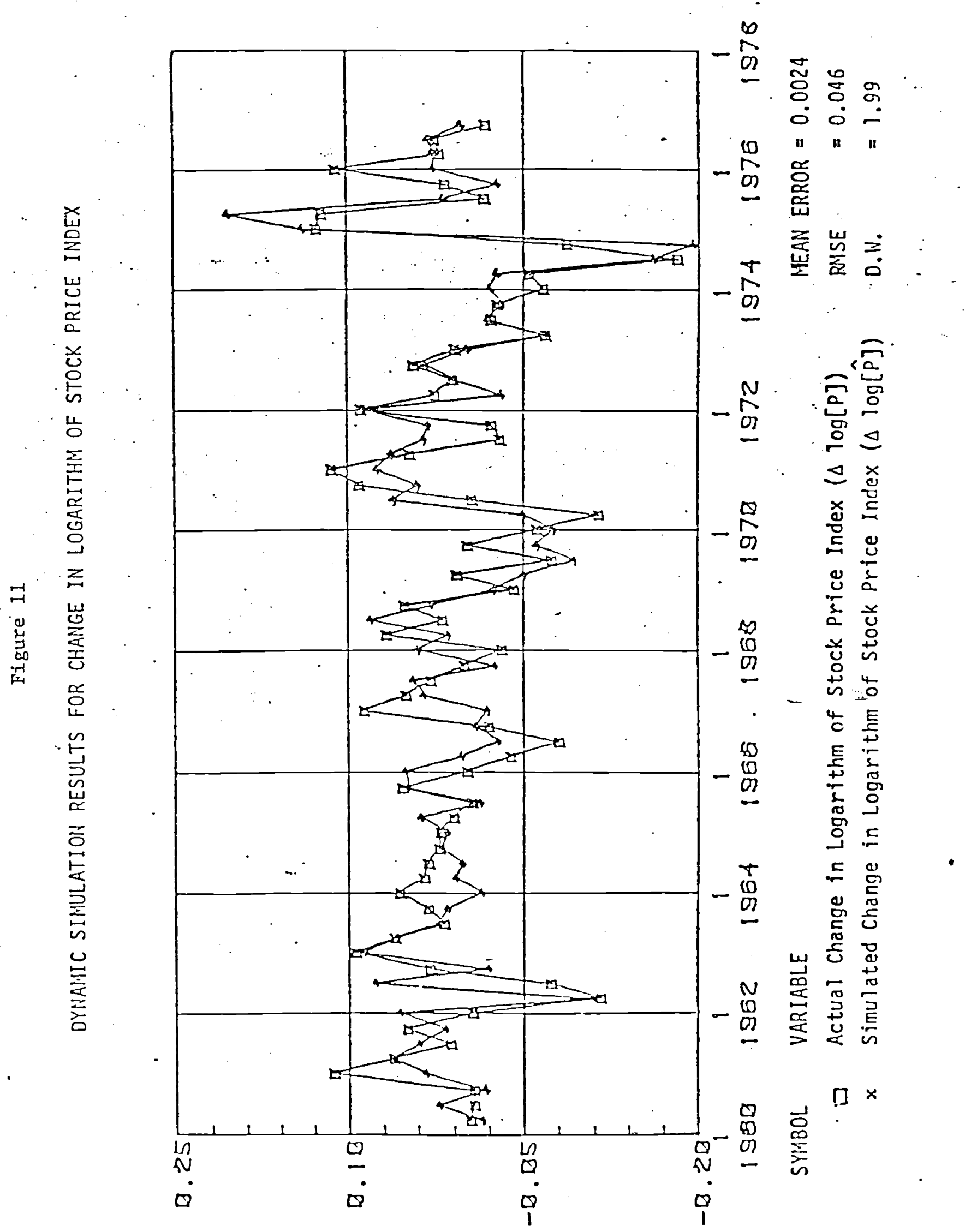
those of Modigliani and Cohn are again in close conformity.

Our final historical tracking exercise is an out-of-sample performance test. This experiment consists of reestimating the equity market model using the sample period 1960:1 - 1974:4 and then simulating this new model dynamically over the period 1975:1 - 1976:4.

The results of this exercise are presented in Figure 12 . It can be seen that the model substantially overpredicts the stock market recovery in 1975. This, however, is not terriby surprising in light of the very depressed level of the stock market in 1974:4.

By 1975:4 the model's stock price predictions begin to come back on track and by 1976:1 the model is tracking stock prices very closely. In fact, the model's predictions are extremely close to the actual values throughout the last three quarters of 1976.

On the whole, the equity market model's out-of-sample tracking performance seems quite respectable given the chaotic period over which this exercise carried out. Unfortunately, Modigliani and Cohn do not report any out-of-sample simulation experiments with their reduced-form equity market model.

To recapitulate, we have shown that our structural model of the U.S. equity market is highly competitive with a well known reduced-form model of the equity market in terms of within-sample forecasting accuracy. The structural model also performs reasonably well in an out-of-sample forecasting exercise. We tentatively conclude, therefore, that the available evidence supports the use of the structural model of the determination of the general level of equity prices. 


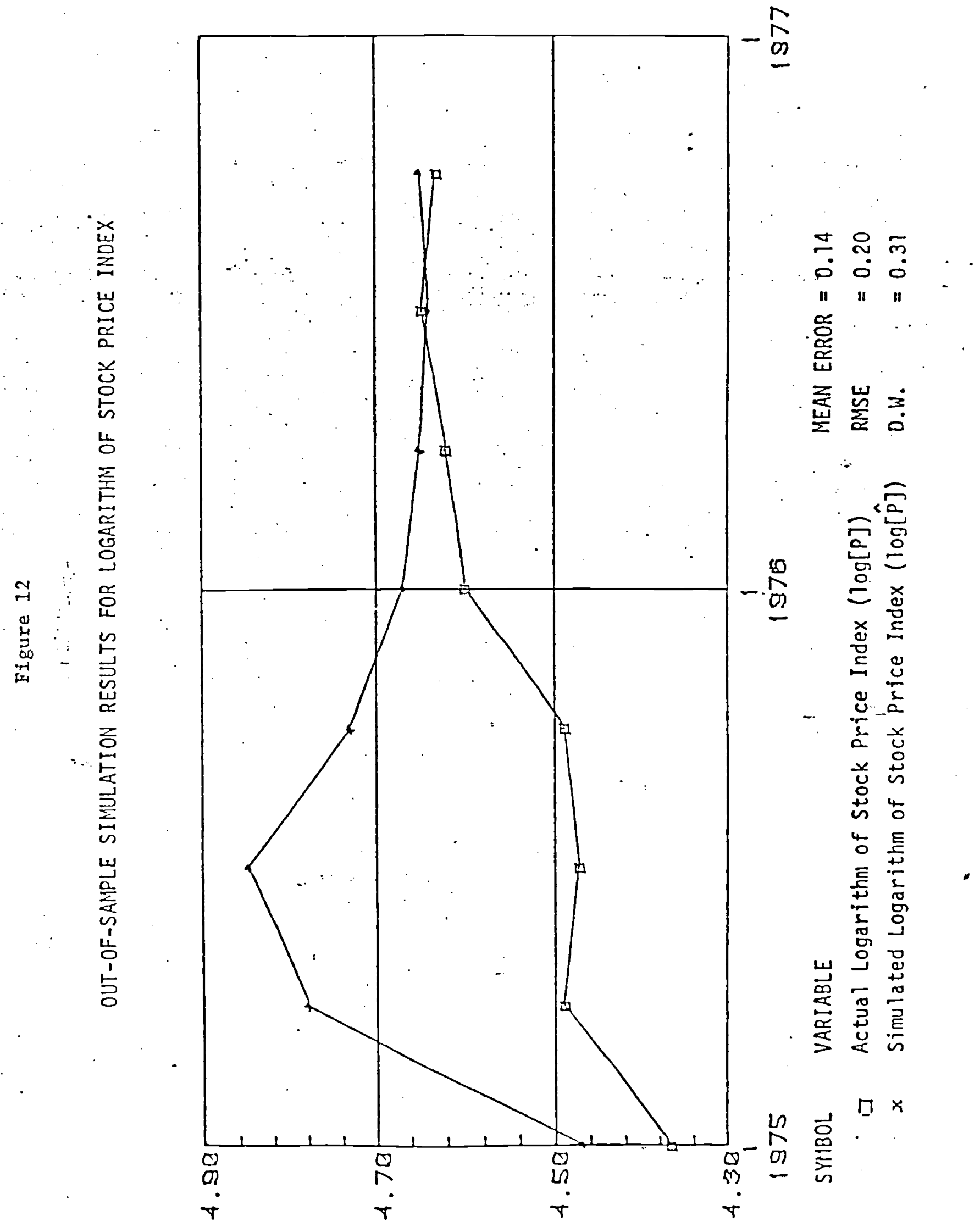




\section{Expected Inflation and Equity Prices}

Figure 13 reports the results of using the above structural equity market model to simulate the effects on equity prices of increases in expected inflation, nominal interest rates, and expected earnings and dividend per share growth rates. When appropriate, comparable results obtained by Modigliani and Cohn are also reported.

To obtain the statistics reported in Figure 13 a static control simulation is compared to a simulation in which the indicated variables are increased above their actual historical values by 100 basis points. Static rather than dynamic simulations are employed to avoid having to adjust other exogenous variables (e.g., wealth flows) to reflect the increases in inflation that would have to occur if investors' inflation expectations are realized. ${ }^{18}$

From Figure 13 we see that a ceterus paribus 100 basis point increase in nominal interest rates is predicted to reduce current stock prices by 9.9\%. This estimate falls well within the $95 \%$ confidence bound of the Modigliani-Cohn estimate of $5.9 \%$.

Holding nominal interest rates fixed, our model predicts that 100 basis point increases in expected inflation and nominal earnings and

dividends per share growth rates will raise current stock prices by $1.9 \%{ }^{19}$ This estimate lies slightly outside the $95 \%$ confidence bound of Modigliani and Cohn's estimate of $-2.1 \%$. Caution must be exercised in interpreting this difference because of the fact that joint confidence bounds for both our "estimate" and Modigliani and Cohn's are not obtainable. Hence, we cannot determine whether or not these two predictions are statistically different. 
Figure 13

MEAN CHANGE IN LOG[P] DUE TO 100 POINT INCREASE IN THE FOLLOWING VARIABLES

STRUCTURAL MODEL ESTIMATES ${ }^{a}$

OF THE MEAN CHANGE IN LOG[P]
MODIGLIANI - COHN

ESTIMATES

NA

$-.059$

NA

NA

$-.021$

$-.080$

Notes: (a) The time interval used for these experiments is 1960:1 1976:4. In each experiment the indicated variables are increased 100 basis points above the actual historical values used in a static control simulation. The number reported above are the mean differences between the $\log [\hat{P}]$ generated by the perturbed and by the control simulations. 
Both Modigliani and Cohn's and our own estimate of this effect are likely to be very imprecise due to the severe collinearity between the inflation variables and the nominal interest rates in our respective regressions. Given the empirical regularity that real interest rates in the U.S. have tended to be relatively constant over time, ${ }^{20}$ both models are likely to give better estimates of the impact of expected inflation holding real, rather than nominal, interest rates fixed. This, moreover, is probably the more realistic and interesting case in any event.

The predicted equity price change holding real interest rates fixed is reported as experiment (6) and Figure 13 . In this case the effect estimated by Modigliani and Cohn $(8 \%)$ is almost identical with the estimate derived from the structural equity market model $(7.8 \%)$. In both models this effect is essentially due to the fact that nominal interest rate effects on equity prices dominate handily the effects of expected inflation per se. Needless to say, the similarity of the above estimates is striking given the different methodologies responsible for generating them.

VII. Conclusions

In this paper we have constructed a structural econometric model of the U.S. equity market and have used this model to estimate the impact of expected inflation on the general level of equity prices. Two major conclusions follow from this study. First, the structural equity market model which we have constructed appears to do at least as well in several standard within-sample historical tracking tests as the well known Modigliani-Cohn reduced-form model. The structural model also performs 
reasonably well in an out-of-sample tracking exercise. It performs well in these model validation tests even though the estimation procedure does not directly focus upon within-sample RMSE. The estimation procedure in most reduced-form models, however, does directly focus on this criterion. Second, the structural equity market model implies that increases in expected inflation holding real interest rates fixed severely depress stock prices. The model estimates that each 100 basis point increase in expected inflation, holding real interest rates fixed, will reduce the general level of equity prices by $7.8 \%$. This estimate is almost identical to that obtained by Modigliani and Cohn who use the alternative reducedform methodology. 


\section{Footnotes}

*I am indebted to Benjamin Friedman and John Lirtner for many helpful discussions. Of course, they are not responsible for any errors which remain.

1. For a proof see Modigliani and Cohn (1979).

2. See Jones (1979) for a discussion of how this specification is motivated.

3. Net acquisition of life insurance and pension reserves are presumed to be contractual rather than discretionary in the short-run.

4. For most life insurance companies policy loans are nondiscretionary investments.

5. Trade credit is presumed to be a nondiscretionary investment for property and casualty insurance companies.

6. The regression equation for this sector is not substanially affected if instead of replacement value the market value is used.

7. Rational expectations were also tried using the approach outlined in Friedman and Roley (1977). In all cases the own yield effect is insignificant when rational expectations are assumed. Friedman and Roley report similar findings.

8. Due to collinearity problems this expression is modeled as a distributed lag of past growth rates of earnings per share in the household equity equation.

9. New wealth flows are taken as exogenous in this study and therefore need not be instrumented. An exception are the new wealth flows of open-end investment companies which are endogenously determined within the equity market model. These wealth flows are instrumented below. For a theoretical discussion of the econometric exogeneity of new wealth flows see Purvis (1978) and Smith (1978).

10. The sample period for state and local government retirement systems is only 1966:1 through 1976:4. See note (e) of Figure 2 for additional details.

11. See Dyl (1977) for a discussion of this effect.

12. Dyl has empirically verified these effects using monthly trading data on individual securities. 
13. As a methodological note, these three ratios are not perfectly collinear (i.e., they do not sum to unity) because several liability categories are excluded from the regression specification. The largest excluded category are insured pension reserves which were $24 \%$ of total assets at the end of 1976.

14. At year-end 1976 these exogenous sectors held only $5.6 \%$ of all equity outstanding.

15. The flow-of-funds series of end-of-quarter equity holdings are interpolations of year-end numbers. They are therefore not very accurate.

16. Equity demands by state and local government retirement systems is treated as exogenous from 1960:1-1965:4 and is treated as fully exogenous thereafter.

17. In a dynamic simulation the lagged endogenous variables which affect stock prices in the current period are those which were endogenously determined by the model in previous periods.

18. See Mishkin (1979) for a related discussion.

19. Modigliani and Cohn implicitly assume in their regression that real earnings per share are unaffected by changes in the rate of inflation. This assumption, they maintain, is supported by the available evidence. As can be seen from Figure 13, the expected growth rates of earnings and dividends have only marginal affects on stock prices in the structural equity market model anyway. Thus, our simulation experiments are fairly insensitive to changes in the assumption of how these growth rates react to changes in inflation.

20. See the references cited by Jones (1979). 